\title{
The bimodal role of matrix metalloproteinases and their inhibitors in etiology and pathogenesis of endometriosis (Review)
}

\author{
MAGDALENIA BAŁKOWIEC $^{1 *}$, RADOSŁAW B. MAKSYM ${ }^{2,3 *}$ and PAWEŁ K. WŁODARSKI ${ }^{2}$ \\ ${ }^{1}$ Department of Histology and Embryology, Medical University of Warsaw, 02-004 Warsaw; \\ ${ }^{2}$ Center for Preclinical Research, Department of Methodology, Medical University of Warsaw, 02-097 Warsaw; \\ ${ }^{3}$ Department of Reproductive Health, Center of Postgraduate Medical Education, 01-004 Warsaw, Poland
}

Received March 8, 2018; Accepted June 19, 2018

DOI: $10.3892 / \mathrm{mmr} .2018 .9303$

\begin{abstract}
Aberrant regulation of matrix metalloproteinases (MMPs) may be the primary cause of endometrial lesion formation in a group of predisposed women. Prospect for the genuine origin of endometriosis is ongoing, since retrograde menstruation leads to presence of endometrial debris in peritoneal cavity of many women, which do not experience endometriosis. Tissue remodeling is regulated precisely by a balance of MMPs and their inhibitors. Interplay between factors enhancing and suppressing matrix turnover is crucial for cyclic preparation of endometrium for embryo implantation, and endometrial shedding and renewal in physiology of primates. Disorders of the regulation of matrix remodeling leads to augmentation of implantation and invasive growth of ectopic endometrial tissue. Moreover, endometriosis-induced changes in the matrix balance leads to adhesion formation, ovulatory dysfunction and fertility impairment. The review summarizes the current knowledge regarding the regulation of extracellular matrix turnover in the physiology of the endometrial cycle and in the development of endometriosis, as well as the pathophysiology of ovulatory dysfunction in endometriotic women. Therapeutic modalities utilizing modulation of tissue remodeling were discussed.
\end{abstract}

\section{Contents}

1. Introduction

2. Matrix metalloproteinases and inhibitors of MMP

Correspondence to: Professor Paweł K. Włodarski, Center of Preclinical Research, Department of Methodology, Medical University of Warsaw, 1B Banacha Street, 02-097 Warsaw, Poland E-mail: pawel.wlodarski@wum.edu.pl

*Contributed equally

Key words: endometriosis, retrograde menstruation, infertility, extracellular matrix remodeling, matrix metalloproteinase, tissue inhibitor of metalloproteinases, RECK
3. Regulation of MMP activity
4. MMP in menstrual effluent
5. MMP in peritoneal fluid
6. Changes of MMPs and TIMPs activity in eutopic endometrium
7. Activity of MMP in ectopic lesions
8. Levels of MMP in serum
9. Polymorphism of MMP genes in endometriosis
10. Future research and treatment perspectives

\section{Introduction}

Endometriosis is a condition defined as presence of endometrium outside of uterine cavity. It is very common, with an incidence of 5-20\% among women in reproductive age, however, its causes still remain obscure. Numerous theories were proposed to explain etiology of endometriosis, reviewed well by Burney and Giudice (1). Unfortunately, a single, sufficient explanation of disease causes is missing, since the origin seems to be connected with miscellaneous factors. It is widely accepted that underlying process leading to endometriosis development is retrograde menstruation, which is an antiperistaltic passage of menstrual debris through Fallopian tubes (2). It has been proven though, that retrograde menstruation is a quite frequent phenomenon that occurs also in women without endometriosis (3), therefore other factors must influence the stages of endometriosis development. The essential process in the disease onset is implantation of endometrial cells into peritoneal surface. Interestingly, during this process endometrial cells demonstrate some features of malignancy, as they are able to attach and to invade structure of peritoneum or ovary, in the similar way as cancer cells cause metastasis. This invasion is effectuated with matrix metalloproteinases (MMPs)-group of enzymes involved in tissue remodeling. This review is dedicated to the role of that group of enzymes and their inhibitors in development and pathogenesis of endometriosis.

\section{Matrix metalloproteinases and inhibitors of MMP}

Group of MMPs is a large family of endopeptidases, that are essential in degradation of extracellular matrix (ECM) and basal membrane (BM). Several subtypes of MMPs are 
distinguished, depending on their substrate-specificity and localization: Collagenases, gelatinases, stromelysins, matrilysins and membrane-type metalloproteinases. We summarize classification and substrate specificity of MMPs in Table I, that was based on BRENDA-The Comprehensive Enzyme Information System database (www.brenda-enzymes.org) (4).

MMPs play a crucial role in numerous physiological processes, for instance: bone remodeling, angiogenesis, inflammation, ovulation and embryogenesis (5). What is more, MMPs are involved in cyclic changes of endometrium structure and thickness in the course of endometrial cycle, feature that is caused by changes in steroid hormones concentration levels. MMPs are expressed in both epithelial and stromal cells, with the exception of MMP-7 that is detected selectively in epithelial compartment (6). Furthermore, metalloproteinases present variable activity during the cycle, what was summarized in Table II $(7,8)$.

Numerous MMPs are additionally involved in many pathological processes (9), such as: fibrosis, weakening of matrix (e.g., in aortic aneurysm or dilated cardiomyopathy) or tissue destruction [e.g., cancer invasiveness, also endometrial carcinoma invasiveness and ability to metastasize (10)]. Therefore, the balance between activation and inhibition of MMPs is crucial for maintaining homeostasis. Their increased activity can cause excessive ECM degradation, while their deactivation-insufficient ECM remodeling. Both can lead to development of versatile medical conditions. Development of novel therapies, that would influence MMPs activity, seems to be promising but unreachable in short order.

The balance in MMPs activity is regulated by a very wide range of factors, which prevents accidental overactivation or suppression of MMPs and therefore help maintaining homeostasis. What is more, the number of known interactions is still growing.

\section{Regulation of MMP activity}

One of the most important means of regulating MMPs activity are interactions with proteins, that inhibit final MMPs activity: Reversion-inducing-cysteine-rich protein with Kazal motifs (RECK) (11) and a group of soluble tissue inhibitor of metalloproteinases (TIMPs) (12). These proteins significantly contribute in ECM remodeling, regulating angiogenesis and inflammatory reactions.

The mechanism of actions of TIMPs and RECK include formation of a stoichiometric complexes between inhibitor and a catalytic region of MMP. Binding blocks MMPs enzymatic activity. MMPs inhibitors are proteins, that have highly conservative sequence among species. Human genome encodes 4 genes coding TIMPs: TIMP1-TIMP4, that vary in substrate specificity (13) (Table III).

Interestingly, TIMPs suppress the activity of not only MMPs, but also proteins from different family of endopeptidases, namely A Disintegrin And Metalloprotease family (ADAM) (14-17). ADAMs also fulfill similar functions in regulating inflammatory responses, cell migration and other aspects of matrix turnover (18). The most active TIMP against ADAMs proteins is TIMP-3, while some other members of this family have only limited regulatory activity; for example, TIMP-1 inhibits ADAM-10 selectively (17).
As summarized by Alexius-Lindgren (19), RECK is membrane-bound MMPs inhibitor, especially active against MMP-9 (11). RECK, similarly to soluble TIMPs, plays a crucial role in ECM remodeling and is involved with metastases and invasiveness of cancer (20). Considering the common features between cancer metastases and endometriosis implants, RECK may be an interesting candidate gene to study in endometriosis development.

In addition to MMPs direct binding by inhibitors, their proteolytic activity is regulated also by cytokines, hormones, growth factors and many other biologically active agents (21-23). Steroid hormones were described as main agents, that have an influence on MMPs activity, especially in endometriosis and endometrial tissue turnover. Progestins are widely used in therapy of the disease, decreasing endometrial growth and endometriosis-associated pelvic pain (24). They were proven to inhibit MMPs secretion by eutopic endometrial cells from uterine cavity (25-27) and ectopic lesions (28), and to enhance TIMP-2 activity (29). Similar effect was achieved by non-steroid progesterone receptor (PR) agonist (30). Meanwhile, estrogenic stimulation was proven to induce MMP-2 and MMP-9 expression (31). Moreover, there is a positive correlation between $17 \beta$-estradiol and MMP-2 serum levels in proliferative phase and a negative correlation between progesterone and MMP-2 serum levels in secretory phase of the cycle (32).

Recent studies focus on non-steroid hormones, that could affect MMPs activity. It was shown, that numerous endocrine factors reduced ectopic lesions development in animal models of endometriosis. MMPs activity and endometrial fragment implantation can be regulated by: Leptin (33), somatostatin (34) and melatonin (35). Discovery of such interactions is very promising, as alternative hormonal therapy in endometriosis would probably be less troublesome than hormonal suppression for patients in reproductive age. However, there are no clinical trials on their effectiveness in humans.

Other factors, that impact ECM remodeling by changing MMPs activity are immune system cells. Their role of uterine leukocyte population in endometriosis development was reviewed by Parkin and Fazleabas (36).

Soluble agents, i.e., cytokines, such as TGF- $\beta 1$, TNF- $\alpha$ and IFN- $\gamma$, IL-1, IL-4 and IL- 8 regulate MMPs and TIMPs expression (37-39). IL-8, also known as neutrophil chemotactic factor, stimulates MMP-2 and MMP-9 expression in endometrium (40). IL-1 $\alpha$ enhances MMP-1 activity in human endometrial fibroblasts and endometrial cells $(27,41)$. Administration of IL- $1 \alpha$ natural decoy-soluble form of IL-1 receptor type 2 (sIL-1R2), influences MMP-2, MMP-9 and TIMP-1, -2 and -3 activity in murine model of endometriosis, simultaneously affecting endometrial ability to invade and grow in ectopic locations (42). On the other hand, administration of IL-4, an anti-inflammatory cytokine, inhibits MMP-3 and MMP-4 expression and reduces number and volume of ectopic lesions in murine model of endometriosis (43). Besides cytokines, other immunological agents: eikosanoides, such as lipoxin A4 and prostaglandin E2, were also proven to alter MMP activity $(44,45)$.

Other regulators of MMPs and TIMPs activity are growth factors: EGF and FGF, that increase MMP-1, MMP-3, MMP-11 and TIMP-1 expression (39,46). Retinoic acid inhibits MMP-3 
Table I. Classification of MMPs.

\begin{tabular}{lll}
\hline Enzyme & Aliases & Substrates in human
\end{tabular}

\begin{tabular}{ll}
\hline MMP-1 & Interstitial collagenase, collagenase 1 \\
MMP-2 & Gelatinase A, 72 kDa gelatinase, 72 kDa \\
& type IV collagenase \\
MMP-3 & Stromelysin 1, progelatinase
\end{tabular}

MMP-7 Matrilysin, PUMP-1, uterine metalloproteinase

MMP-8 Neutrophil collagenase, PMNL collagenase

MMP-9 Gelatinase B, 92 kDa gelatinase, $92 \mathrm{kDa}$ type IV collagenase

MMP-10 Stromelysin-2, transin-2

MMP-11 Stromelysin-3

MMP-12 Metalloelastase, macrophage metalloelastase, macrophage elastase

MMP-13 Collagenase 3

MMP-14 Membrane type-1-matrix metalloproteinase (MT1-MMP)

Collagen I, II, III, casein, gelatin, $\alpha 2$-macroglobulin Collagen I, IV, V, elastin, fibrilline, fibrinogen, fibronectin, galectin-3, gelatin, laminin, vitronectin Collagen I, IV, V, IX, X, $\alpha 1$-antitrypsin, $\alpha 1$-proteinase inhibitor, antithrombin III, casein, decorin, elastine, fibrillin, fibrin, fibronectin, gelatin, interleukin (IL)-1b, laminin, osteopontin, pro-MMP-1, tumor necrosis factor- $\alpha$ (TNF- $\alpha$ ) precursor, Apaf-1, pro-caspase-9

Collagen IV, aggrecan, annexin II, $\beta$-casein, $\beta 4$ integrin, connexin, E-cadherin, defensin, elastin, fibronectin, Fas-ligand, gelatin, insulin-like growth factor-binding protein-3 (IGFBP-3), laminin, nidogen, osteopontin, perlecan, plasminogen, tumor necrosis factor (TNF- $\alpha$ ) precursor, syndecan, tenacin-C, tumor-associated antigen $90 \mathrm{~K}$

Collagen I, II, III, estrogen receptor $\alpha$ and $\beta$, TNF- $\alpha$; serpins, bradykinin, angiotensin I, substance $\mathrm{P}$

Collagen I, III, IV, V, XI, actin, $\alpha$-enolase, annexin I crystallin, epidermal growth factor, ezrin, filamin B, galectin-3, gelatin, gelsollin, heat shock proteins, laminin, moesin, nucleolin, stathmin, stromelysin 1, tubulin, vitronectin

Collagen IV, V, IX, X, casein, elastin, fibrillin, fibronectin, gelatin, laminin, procollagenase (pro-MMP1)

Collagen IV, VI, IX, $\alpha 1$-antitrypsin, $\alpha 1$-protease inhibitor, casein, elastin, fibronectin, insulin-like growth factor-binding protein-1 (IGFBP-1), laminin

Collagen I, III, IV, $\alpha 1$-antitrypsin, $\beta$-casein, elastin, enactin, fibronectin, gelatin, laminin, plazminogen, TNF- $\alpha$, vitronectin

Collagen I, II, III, IV, VI, IX, 'X, XIV, $\alpha 2$-macroglobullin, antichymotrypsin, $\beta$-casein, decorin, factor XII, fibrillin, fibrinogen, fibronectin, gelatin, laminin, plasminogen activator inhibitor, serglycin, TIMP1, transforming growth factor $\beta$ (TGF- $\beta$ ), xylosyltransferase 1

Collagen I, II, III, $\alpha-1$ microglobulin, $\alpha-2$ macroglobulin, $\alpha$-2-HS-glycoprotein, $\alpha 1$-antitrypsin, $\alpha 1$-proteinase inhibitor, $\alpha 5$ integrin, apolipoprotein $\mathrm{A}$, apolipoprotein $\mathrm{E}$ and apolipoprotein $\mathrm{J}$, brain-specific angiogenesis inhibitor 1, casein, CD44, fibrin II, E-cadherin, elastin, endoglin, entactin, epidermal growth factor receptor, extracellular matrix metalloproteinase inducer, gelatin, fibrillin, fibrin, fibrinogen, fibroblast growth factor recetor (FGFR) 1 and 4, fibronectin, galectin-3, gelsolin, growth differentiation factor-1, heparin-binding epidermal growth factor, hepatocyte growth factor activator inhibitor- 1 , inter- $\alpha$ inhibitor $\mathrm{H} 4$, intercellular cell adhesion molecule-1, kidney injury molecule-1, Kisspeptin/metastin, laminin, mannose-binding lectin, mucin 1, N-cadherin, Notch1, pro-MMP-2, -8 and -13, pro-transforming growth factor $\beta$, progelatinase $\mathrm{A}$, receptor-activator of NF-kB ligand, stromal cell-derived factor 1 , testican-1, transforming growth factor- $\beta$, transglutaminase, vitronectin 
Table I. Continued.

\begin{tabular}{|c|c|c|}
\hline Enzyme & Aliases & Substrates in human \\
\hline MMP-15 & $\begin{array}{l}\text { Membrane type-2 matrix metalloproteinase } \\
\text { (MT2-MMP, MTMMP2) }\end{array}$ & $\begin{array}{l}\text { Weak collagenase activity; cell surface tissue transglutaminase, } \\
\text { fibronectin, laminin, pro-MMP- } 2 \text { and }-13 \text {, tenascin }\end{array}$ \\
\hline MMP-16 & MT3-MMP, MTMM3 & Collagen III, casein, fibronectin, gelatin, pro-MMP-2 \\
\hline MMP-17 & MT4-MMP, MTMM4 & $\begin{array}{l}\text { MT4-MMP acts as a TNF- } \alpha \text {-converting enzyme, and as a } \\
\text { glycosylphosphatidylinositol-anchored enzyme }\end{array}$ \\
\hline MMP-19 & RASI-1 MMP-18 (precursor of MMP-19) & Very limited activity versus gelatin; tenascin $\mathrm{C}$ \\
\hline MMP-20 & Enamelysin, enamel metalloproteinase & Collagen V, amelogenin, enamel protein, endostatin \\
\hline MMP-21 & HTX7 & $\alpha 1$-proteinase inhibitor \\
\hline MMP-23B & $\begin{array}{l}\text { Femalysin, matrix metalloproteinase in the } \\
\text { female reproductive tract, MIFR, MIFR-1 }\end{array}$ & \\
\hline MMP-24 & MT5-MMP-5, МТMMP5 & Gelatin, fibronectin, pro-MMP-2 \\
\hline MMP-25 & MT6-MMP, MMP-20, MMPL1 & $\begin{array}{l}\text { Collagen IV, } \alpha 1 \text {-proteinase inhibitor, fibrin, fibronectin, } \\
\text { gelatin, pro-MMP-2 }\end{array}$ \\
\hline MMP-26 & Matrilysin-2, endometase & $\begin{array}{l}\text { Collagen IV, } \alpha 1 \text {-antitrypsin, } \alpha 2 \text {-macroglobulin, fibronectin, } \\
\text { fibrinogen, insulin-like growth factor-binding } \\
\text { protein } 1 \text { (IGFBP-1), plazminogen, pro-MMP-9, vitronectin }\end{array}$ \\
\hline MMP-27 & - & Casein, gelatin \\
\hline MMP-28 & Epilysin & Casein, NCAM \\
\hline
\end{tabular}

Examples of their substrates. Source: BRENDA-The Comprehensive Enzyme Information System (4).

and MMP-7 secretion (47), and expression of extracellular matrix metalloproteinase inducer (EMMPRIN), a glycoprotein that was first discovered in tumor cells, which increases MMP-1 and MMP-2 expression (48).

Factors presented above act simultaneously and affect each other. For example, Bruner et al reported, that progesterone requires TGF- $\beta$ for its action and that progesterone and TGF- $\beta$ cooperate in MMPs secretion inhibition (49). Moreover, immunological impact on endometriosis development can be prevented by both steroid hormones or retinoic acid $(41,47)$. Those findings among others are an evidence, that no single factor is a master switch in MMPs and TIMPs regulations and subsequently in endometriosis etiology.

\section{MMP in menstrual effluent}

As mentioned above, assumption of the pivotal role of retrograde menstruation is the most widely accepted theory explaining etiology of endometriosis. Studies performed in vitro showed, that endometrial cells can attach to intact peritoneum and invade through the mesothelium within 18-24 h (50), concomitantly causing changes in morphology of the surface (51). Those initial steps of ectopic lesions development require MMPs activity for basement membrane and ECM breakdown and subsequent invasion into the stroma. High levels of numerous MMPs in endometrium during menstruation $(7,52)$ and blockage of ectopic lesions formation in murine model of endometriosis after TIMP-1 intraperitoneal treatment (53) are solid arguments for MMPs crucial role in endometriosis onset.

Noteworthy, the retrograde menstruation does not seem to be anomaly, as it is quite common and is observed both in women with and without endometriosis (3). What is more, no difference was found in menstrual effluent volume and MMP-2 and MMP-9 levels in menstrual blood of women with endometriosis and in healthy control (54). In conclusion, retrograde menstruation itself could be considered more as a condition and not as the only or main cause of ectopic endometrial lesions occurrence. Other molecular, genetic, hormonal and immunological factors could have significant contribution to disease development.

\section{MMP in peritoneal fluid}

As retrograde menstruation is not sufficient to initiate ectopic lesions in peritoneum, the peritoneum has to provide a microenviroment for implant invasion. Numerous studies show altered cytokine levels and balance in peritoneal fluid collected from patients with endometriosis (55-57), and, as mentioned above, cytokines are potent regulators of MMPs activity. It remains undetermined, whether the imbalance is a cause and not a secondary result of ectopic lesions presence. Anyway, the immunological reactions ongoing in peritoneum may influence balance between MMPs and their inhibitors in endometriotic early implants and therefore augment endometriosis onset or further development. This theory is supported by the finding, that uterine endometrial cells cultivated in medium containing peritoneal fluid collected from women with endometriosis are characterized by MMP-2 overexpression (58).

Peritoneal fluid collected from women with endometriosis shows elevated levels of MMPs and decreased levels of its inhibitors. MMP-2 (32), MMP-3 (59) and MMP-9 $(60,61)$ levels were significantly higher in peritoneal fluid of women with endometriosis than in healthy control, while TIMP-1 levels were lower (61). However, no differences were found 
Table II. Relative expression of various MMPs and TIMPs through the menstrual cycle.

\begin{tabular}{|c|c|c|c|c|c|c|c|}
\hline \multirow[b]{3}{*}{ Protein } & \multicolumn{7}{|c|}{ Menstrual cycle phase } \\
\hline & \multicolumn{2}{|c|}{ Menstrual } & \multicolumn{2}{|c|}{ Proliferative } & \multicolumn{3}{|c|}{ Secretory } \\
\hline & Early & Late & Early & Late & Early & Mid & Late \\
\hline MMP-1 & ++++ & ++++ & + & + & + & + & + \\
\hline MMP-2 & +++ & +++ & ++ & ++ & ++ & ++ & ++ \\
\hline MMP-3 & ++++ & ++++ & + & + & + & + & + \\
\hline MMP-7 & ++++ & ++++ & ++++ & ++++ & + & + & + \\
\hline MMP-8 & ++++ & ++ & + & + & + & + & + \\
\hline MMP-9 & ++ & ++ & + & + & + & + & + \\
\hline MMP-10 & ++++ & ++++ & ++ & ++ & + & ++ & ++ \\
\hline MMP-11 & ++++ & ++++ & ++++ & ++++ & + & + & + \\
\hline MMP-12 & ++++ & + & + & + & + & + & + \\
\hline MMP-14 & +++ & +++ & ++ & ++ & ++ & ++ & ++ \\
\hline MMP-15 & ++ & ++ & ++ & ++ & ++ & ++ & ++ \\
\hline MMP-16 & + & + & ++ & ++ & ++ & + & + \\
\hline MMP-19 & ++ & ++ & ++ & ++ & ++ & ++ & ++ \\
\hline MMP-26 & + & + & ++ & ++ & ++++ & ++ & + \\
\hline TIMP-1 & ++ & ++ & ++ & ++ & ++ & ++ & ++ \\
\hline TIMP-2 & ++ & ++ & ++ & ++ & ++ & ++ & ++ \\
\hline TIMP-3 & ++++ & ++ & ++ & ++ & ++ & ++ & ++++ \\
\hline TIMP-4 & + & + & + & ++ & ++++ & ++ & + \\
\hline
\end{tabular}

Minimal expression, +; Strong expression, ++++; and Moderate expression, ++ and +++. MMP, matrix metalloproteinase; TIMP, tissue inhibitor of metallopeptidase.

Table III. Characterization of substrate specificity of TIMPs.

\begin{tabular}{|c|c|c|c|c|}
\hline Variable & TIMP-1 & TIMP-2 & TIMP-3 & TIMP-4 \\
\hline $\begin{array}{l}\text { Activity against } \\
\text { MMPs }\end{array}$ & $\begin{array}{l}\text { Membrane-type MMPs } \\
\text { (MT1-, MT3-, MT5-MMP) } \\
\text { MMP-19 }\end{array}$ & $\begin{array}{l}\text { Very wide activity } \\
\text { (weaker inhibition of MMP-3 } \\
\text { and MMP-7 in comparison } \\
\text { to TIMP-1) }\end{array}$ & $\begin{array}{l}\text { Very wide activity } \\
\text { (weaker inhibition of MMP-3 } \\
\text { and MMP-7 in comparison } \\
\text { to TIMP-1) }\end{array}$ & $\begin{array}{l}\text { Active against } \\
\text { most MMPs }\end{array}$ \\
\hline $\begin{array}{l}\text { Activity against } \\
\text { ADAMs }\end{array}$ & ADAM-10 & ADAM-12 & $\begin{array}{l}\text { ADAM-10, }-12,-17,-28-33 \text {, } \\
\text { ADAMTSs }\end{array}$ & ADAM-17, -28 \\
\hline Other functions & $\begin{array}{l}\text { EPA-erythroid-potentiating } \\
\text { activity } \\
\text { Anti-apoptotic }\end{array}$ & $\begin{array}{l}\text { EPA-erythroid-potentiating } \\
\text { activity } \\
\text { Anti-apoptotic }\end{array}$ & $\begin{array}{l}\text { Inhibits angiogenesis } \\
\text { Pro-apoptotic }\end{array}$ & \\
\hline $\begin{array}{l}\text { Interaction with } \\
\text { pro-MMP }\end{array}$ & Pro-MMP-9 & Pro-MMP-2 & $\begin{array}{l}\text { Pro-MMP-2 } \\
\text { Pro-MMP-9 }\end{array}$ & Pro-MMP-2 \\
\hline
\end{tabular}

MMP, matrix metalloproteinase; TIMP, tissue inhibitor of metallopeptidases.

between the groups in TIMP-2 levels, and MMP-13 levels in peritoneal fluid were lower in women with endometriosis than in healthy control (62).

Interestingly, although sex hormones are one of the most significant regulators of MMPs activity, no correlations between steroid hormones levels and MMP-9 (61) and TIMP-1 (63) activity in peritoneal fluid was found. This supports the theory, that there are the additional factors, that play a role in endometriosis early formation. However, once lesion appear, hormonal factors affect its growth and activity, causing cyclic changes and bleeding. Therefore hormonal treatment, that reduces the cyclic pattern and the level on endogenous hormones, is usually the first step in endometriosis management. Those relations have been proven by many studies. Among first 
findings on the issue is good to mention studies from 1990s, that showed reduction of hormone level in peritoneal fluid by gonadotropin-releasing hormone agonist (GnRH-a) in rat endometriosis model (64). Moreover, in women with endometriosis treated with weak androgen danazol, TIMP-1 level in peritoneal fluid returned to normal (63). Therefore, although hormonal factors have a questionable role in endometriosis onset, they clearly participate in its development.

\section{Changes of MMPs and TIMPs activity in eutopic endometrium}

Studies revealing differences in MMPs and TIMPs activity in uterine endometrium collected from women with endometriosis and from healthy subjects, largely contributed to research on endometriosis. However, they do not fully clarify, whether MMPs or their inhibitors deregulation in eutopic endometrium is a primary pathology, that lead to disease development, or secondary reaction to ectopic lesions. Those abnormalities may also be secondary to occurrence of peritoneal lesions, which subsequently cause immunological or hormonal deregulation, that eventually influence uterine endometrium. Similar activity of MMPs in menstrual effluent of healthy and affected women militate for the first theory. Despite of the origins of the imbalance, although uterine endometrium from healthy women and women with endometriosis are structurally similar, wide range of biochemical and molecular differences are found between them (65). Endometrium derived from women with endometriosis shows higher proteolytic activity than from healthy controls (66). However, when comes to activity of specific MMPs and TIMPs in those two clinical groups, numerous opposing results were published. This may be caused by variability of MMPs activity during menstrual cycle or usage of different research methods, that present variable sensitivity and specificity for tested issues. For example, Colette et al found no statistically significant changes in MMP-9 level in uterine endometrium from study and control group, when tested by quantitative polymerase chain reaction (qPCR); however, the differences were significant, when using enzyme-linked immunosorbent assay (ELISA) or zymography (67). Reports on these conflicting results are summarized in Table IV $(58,59,66-78)$.

As presented in the Table IV, wide range of studies focused on MMP-2, -3, -9 and TIMP-1. Nevertheless, obtained results are unsettling, as even samples collected in one specific phase of the cycle and choosing the same method of measurement, gave totally non-reproducible outcomes. Partial explanation to this phenomenon could be various processes taking place in ectopic lesions, that would influence eutopic endometrium in a paracrine way. Newly formed lesions, with implantation process in progress, show different MMPs and TIMPs activity and cytokines levels than mature lesions with fibrosis and immune reaction on site. Therefore, uterine endometrium derived from women with endometriosis may show different MMPs and TIMPs activity, depending on ongoing processes in ectopic lesions and the disease stage.

\section{Activity of MMP in ectopic lesions}

Numerous studies were performed to explain the relationships between MMPs levels in ectopic lesions and eutopic endometrium; similarly to results for uterine endometrium, it is quite common, that conflicting observations are reported. Those differences may be caused by wide range of reasons and could occur at any step of the study: choice of study group (e.g., different endometriosis stages or different phase of menstrual cycle), various types of ectopic lesions (e.g., peritoneal lesions, ovarian endometrioma wall fragments, endometrial tumors, pigmented or non-pigmented lesions), usage of different techniques (qPCR, western blotting and immunohistochemistry) or even different method of statistical analysis.

Endometriosis stage may affect results of MMPs assessment, as they are most active in early changes. Lu et al showed, that implantation of endometrium fragments in peritoneum in mouse model of endometriosis significantly increases MMP-2 level on site (79). Similarly, in murine model of endometriosis performed by Sotnikova et al, MMP-2 levels were also the highest in early ectopic changes and decreased in time, while TIMP-2 levels were acting the opposite way-decreased after transplantation and gradually increased (58). Moreover, in rat model of endometriosis, ectopic endometrial tissue showed higher expression of MMP-3 than uterine endometrium, and this relation was also the strongest in early lesions (80). Ueda et al spotlighted, that MMPs levels may also differ in pigmented and non-pigmented ectopic lesions (81). What is more, MMPs activity also differs in different types of ectopic lesions: retrovaginal, peritoneal or ovarian (71). For example, MMP-1 is active in red peritoneal and ovarian lesions, and inactive in black peritoneal and retrovaginal lesions (82) and MMP-27 is present in ovarian and peritoneal, but absent in retrovaginal lesions (83).

As mentioned before, MMPs levels in uterine endometrium vary significantly througout menstrual cycle; Mizumoto et al showed, that it also applies to ectopic changes (84). All that lead to a conclusion, that studies on MMPs especially on humans are very hard to conduct and to analyze, as high number of unrecognized factors may affect analysis of their outcomes.

All papers known to the authors, that compare MMPs and TIMPs levels in ectopic lesions and homologues eutopic endometrium are summarized in Table V $(68,70,72-78,85-88)$. The results of previous studies are quite consistent when it comes to MMP-2 activity. Most of the studies spotlight higher activity of MMP-2 in ectopic lesions in comparison to uterine endometrium.

However, some studies use different type of control and investigate differences between MMPs and TIMPs activity in endometriotic lesions and uterine endometrium from healthy control [summarized in Table VI $(58,73,75,76,81,83,89,90)]$. This kind of analysis also seems to be informative in endometriosis research, since it compares 'most pathologic' with totally healthy tissue. In ectopic changes vs. homologous uterine endometrium analysis, the deregulation of MMPs-TIMPs balance is hard to see in ectopic lesions, as eutopic endometrium is also affected by the disease. What is more, in majority of those studies, no attention has been paid to phase of menstrual cycle during samples collection, which makes the results quite unreliable and straitened to analyze.

\section{Levels of MMP in serum}

Endometriosis firm diagnosis requires laparoscopic surgery, which is an invasive procedure performed in general anesthesia. This is why numerous studies are conducted in order 
Table IV. Alterations in MMP's/TIMP's expression in eutopic endometrium in endometriosis vs. control endometrium. ${ }^{\mathrm{a}}$

\begin{tabular}{|c|c|c|c|c|}
\hline First author, year & MMP-no. & Obtained result & $\begin{array}{c}\text { Method used and } \\
\text { phase of menstrual cycle }\end{array}$ & (Refs.) \\
\hline Di Carlo, 2009 & MMP-1 & $\begin{array}{l}\text { Increased in women with } \\
\text { endometriosis }\end{array}$ & qPCR, IHC, secretory & (68) \\
\hline Collette, 2004 & MMP-2 & No difference & Zymography, ELISA; in cell culture & $(66)$ \\
\hline Di Carlo, 2009 & & & IHC, secretory & $(68)$ \\
\hline Szymanowski, 2016 & & & qPCR, secretory & (69) \\
\hline Wenzl, 1998 & & & $\begin{array}{l}\text { IHC, results evaluated irrespective } \\
\text { of the phase }\end{array}$ & $(70)$ \\
\hline Uzan, 2004 & & & IHC, whole cycle & (71) \\
\hline Sotnikova, 2010 & & $\begin{array}{l}\text { Increased in women } \\
\text { with endometriosis }\end{array}$ & qPCR, PNS & $(58)$ \\
\hline Di Carlo, 2009 & & & qPCR, secretory & $(68)$ \\
\hline Chung, 2002 & & & qPCR and zymography, whole cycle & (72) \\
\hline Gilabert-Estellés, 2007 & MMP-3 & No difference & qPCR and ELISA, proliferative & (59) \\
\hline Gilabert-Estellés, 2007 & & $\begin{array}{l}\text { Increased in women } \\
\text { with endometriosis }\end{array}$ & qPCR and ELISA, secretory & $(59)$ \\
\hline Gilabert-Estellés, 2003 & & & qPCR, whole cycle & (73) \\
\hline Ramón, 2005 & & & qPCR, ELISA, PNS & (74) \\
\hline Uzan, 2004 & & $\begin{array}{l}\text { Decreased in women } \\
\text { with endometriosis }\end{array}$ & IHC, whole cycle & (71) \\
\hline Collette, 2006 & MMP-9 & No difference & qPCR, PNS & (67) \\
\hline Szymanowski, 2016 & & & qPCR, secretory & (69) \\
\hline Chung, 2001 & & & qPCR, whole cycle & (75) \\
\hline Collette, 2004 & & $\begin{array}{l}\text { Increased in women } \\
\text { with endometriosis }\end{array}$ & Zymography, ELISA; in cell culture & $(66)$ \\
\hline Collette, 2006 & & & Zymography, ELISA, PNS & (67) \\
\hline Di Carlo, 2009 & & & qPCR, IHC, secretory & (68) \\
\hline Pan, 2008 & & & Western blotting, whole cycle & (76) \\
\hline Uzan, 2004 & MMP-11 & $\begin{array}{l}\text { Decreased in women } \\
\text { with endometriosis }\end{array}$ & IHC, whole cycle & (71) \\
\hline Chung, 2002 & MT1-MMP & $\begin{array}{l}\text { Increased in women } \\
\text { with endometriosis }\end{array}$ & qPCR, secretory phase & $(72)$ \\
\hline Gaetje, 2007 & MT5-MMP & $\begin{array}{l}\text { Increased in women } \\
\text { with endometriosis }\end{array}$ & qPCR, PNS & $(77)$ \\
\hline Gilabert-Estellés, 2007 & TIMP-1 & No difference & $\begin{array}{l}\text { qPCR and ELISA, proliferative; } \\
\text { qPCR secretory }\end{array}$ & $(59)$ \\
\hline Collette, 2004 & & & ELISA, proliferative & $(66)$ \\
\hline Collette, 2006 & & & qPCR and ELISA, PNS & $(67)$ \\
\hline Szymanowski, 2016 & & & qPCR, secretory & (69) \\
\hline Gilabert-Estellés, 2003 & & & ELISA, whole cycle & (73) \\
\hline Laudanski, 2014 & & & Western blotting, ELISA, proliferative & (78) \\
\hline Gilabert-Estellés, 2007 & & $\begin{array}{l}\text { Increased in women } \\
\text { with endometriosis }\end{array}$ & ELISA, secretory & $(59)$ \\
\hline Laudanski, 2014 & & & qPCR, proliferative & $(78)$ \\
\hline Collette, 2004 & & $\begin{array}{l}\text { Decreased in women } \\
\text { with endometriosis }\end{array}$ & ELISA, secretory & $(66)$ \\
\hline Sotnikova, 2004 & TIMP-2 & $\begin{array}{l}\text { Increased in women } \\
\text { with endometriosis }\end{array}$ & qPCR, PNS & (58) \\
\hline Chung, 2002 & & $\begin{array}{l}\text { Decreased in women } \\
\text { with endometriosis }\end{array}$ & qPCR, proliferative & $(72)$ \\
\hline Chung, 2001 & TIMP-3 & No difference & qPCR, proliferative & (75) \\
\hline
\end{tabular}


Table IV. Continued.

\begin{tabular}{lll}
\hline First author, year & Obtained result & $\begin{array}{c}\text { Method used and } \\
\text { phase of menstrual cycle }\end{array}$ \\
\hline Chung, 2001 & MMP-no. & $\begin{array}{l}\text { Decreased in women } \\
\text { with endometriosis }\end{array}$ \\
\hline
\end{tabular}

a Summary of literature comprising used method and phase of menstrual cycle. qPCR, quantitative polymerase chain reaction; IHC, immunohistochemistry; ELISA, enzyme-linked immunosorbent assay. Proliferative/secretory/whole cycle refers to phases of menstrual cycle. PNS, menstrual phase not specified.

Table V. Alterations in MMP's/TIMP's expression in ectopic lesions vs. autologus eutopic endometrium. ${ }^{\text {a }}$

\begin{tabular}{|c|c|c|c|c|}
\hline First author, year & MMP-no. & Obtained result & $\begin{array}{l}\text { Method used and phase of } \\
\text { menstrual cycle }\end{array}$ & (Refs.) \\
\hline Di Carlo, 2009 & MMP-1 & Higher in ectopic than eutopic & IHC, qPCR, secretory phase & $(68)$ \\
\hline Shaco-Levy, 2008 & MMP-2 & No difference & IHC, proliferative & $(85)$ \\
\hline Di Carlo, 2009 & & Higher in ectopic than eutopic & IHC, qPCR, secretory & $(68)$ \\
\hline Wenzl, 1998 & & & $\begin{array}{l}\text { IHC, results evaluated irrespective } \\
\text { of the phase }\end{array}$ & (70) \\
\hline Londero, 2012 & & & IHC, whole cycle & $(86)$ \\
\hline Chung, 2002 & & Lower in ectopic than eutopic & qPCR, proliferative & $(72)$ \\
\hline Gilabert-Estellés, 2003 & MMP-3 & Lower in ectopic than eutopic & ELISA, PNS & $(73)$ \\
\hline Meola, 2010 & & & qPCR, proliferative & $(87)$ \\
\hline Di Carlo, 2009 & MMP-9 & No difference & IHC, secretory & $(68)$ \\
\hline Chung, 2001 & & & qPCR, proliferative & $(75)$ \\
\hline Pan, 2008 & & & Western blotting, whole cycle & (76) \\
\hline Di Carlo, 2009 & & Higher in ectopic than eutopic & qPCR, secretory & $(68)$ \\
\hline Chung, 2001 & & & qPCR, secretory & $(75)$ \\
\hline Shaco-Levy, 2008 & & & IHC, proliferative & $(85)$ \\
\hline Liu, 2002 & & & Zymography, PNS & $(88)$ \\
\hline Chung, 2002 & MT1-MMP & No difference & qPCR, proliferative & $(72)$ \\
\hline Londero, 2012 & & Higher in ectopic than eutopic & IHC, whole cycle & $(86)$ \\
\hline Chung, 2002 & & Lower in ectopic than eutopic & qPCR, secretory & $(72)$ \\
\hline Gaetje, 2007 & MT5-MMP & Higher in ectopic than eutopic & qPCR, PNS & $(77)$ \\
\hline Gilabert-Estellés, 2003 & TIMP-1 & Higher in ectopic than eutopic & ELISA, PNS & $(73)$ \\
\hline Ramón, 2005 & & & qPCR, ELISA, PNS & $(74)$ \\
\hline Londero, 2012 & TIMP-2 & Higher in ectopic than eutopic & IHC, whole cycle & $(86)$ \\
\hline Laudanski, 2014 & & Lower in ectopic than eutopic & qPCR, proliferative & $(78)$ \\
\hline Chung, 2001 & TIMP-3 & No difference & qPCR, whole cycle & $(75)$ \\
\hline
\end{tabular}

${ }^{\text {aS }}$ ummary of literature comprising used method and phase of menstrual cycle. qPCR, quantitative polymerase chain reaction; IHC, immunohistochemistry; ELISA, enzyme-linked immunosorbent assay. Proliferative/secretory/whole cycle refers to phases of menstrual cycle. PNS, menstrual phase not specified.

to find a sensitive and specific biomarker for endometriosis, that would allow the non-invasive diagnosis. Despite many attempts, no such protein or index based on a group of protein expression levels has been found so far, that would meet the terms of both: High sensitivity and high specificity (91). MMPs and TIMPs activity in serum was also investigated and showed 
Table VI. Alterations in level of MMP's/TIMP's in ectopic lesion in relation to control endometrium. ${ }^{\text {a }}$

\begin{tabular}{|c|c|c|c|c|}
\hline First author, year & MMP-no. & Obtained result & $\begin{array}{l}\text { Method used and phase } \\
\text { of menstrual cycle }\end{array}$ & (Refs.) \\
\hline Gottschalk, 2000 & MMP-1 & $\begin{array}{l}\text { Higher in ectopic lesion } \\
\text { than healthy control }\end{array}$ & IHC, PNS & (89) \\
\hline Gottschalk, 2000 & MMP-2 & No difference & IHC, PNS & (89) \\
\hline Sotnikova, 2010 & & $\begin{array}{l}\text { Higher in ectopic lesion } \\
\text { than healthy control: }\end{array}$ & qPCR, PNS & (58) \\
\hline Ueda, 2002 & & & qPCR, PNS & $(81)$ \\
\hline Ria, 2002 & & & In situ hybridization, PNS & $(90)$ \\
\hline Gottschalk, 2000 & MMP-3 & No difference & IHC, PNS & (89) \\
\hline Gilabert-Estellés, 2003 & & & ELISA, PNS & (73) \\
\hline Gottschalk, 2000 & MMP-9 & No difference & IHC, PNS & (89) \\
\hline Pan, 2008 & & $\begin{array}{l}\text { Higher in ectopic lesion } \\
\text { than healthy control: }\end{array}$ & Western blotting, whole cycle & (76) \\
\hline Ueda, 2002 & & & qPCR, PNS & $(81)$ \\
\hline Ria, 2002 & & & In situ hybridization, PNS & (90) \\
\hline Cominelli, 2014 & MMP-27 & $\begin{array}{l}\text { Higher in ectopic lesion } \\
\text { than healthy control }\end{array}$ & $\begin{array}{l}\text { qPCR, PNS; one-tailed Wilcoxon } \\
\text { signed rank test only }\end{array}$ & (83) \\
\hline Ueda, 2002 & MT1-MMP & $\begin{array}{l}\text { Higher in ectopic lesion } \\
\text { than healthy control }\end{array}$ & qPCR, PNS & $(81)$ \\
\hline Gilabert-Estellés, 2003 & TIMP-1 & $\begin{array}{l}\text { Higher in ectopic lesion } \\
\text { than healthy control }\end{array}$ & ELISA, PNS & (73) \\
\hline Sotnikova, 2010 & TIMP-2 & No difference & qPCR, PNS & $(58)$ \\
\hline Chung, 2001 & TIMP-3 & No difference & qPCR, proliferative & (75) \\
\hline Chung, 2001 & & $\begin{array}{l}\text { Lower in ectopic endometrium } \\
\text { than healthy control: }\end{array}$ & qPCR, secretory & (75) \\
\hline
\end{tabular}

${ }^{\text {aS }}$ ummary of literature comprising used method and phase of menstrual cycle. qPCR, quantitative polymerase chain reaction; IHC, immunohistochemistry; ELISA, enzyme-linked immunosorbent assay. Proliferative/secretory/whole cycle refers to phases of menstrual cycle. PNS, menstrual phase not specified.

different levels in women with endometriosis than in healthy controls: MMP-2 and MMP-9 levels were higher $(32,60)$, and TIMP-1 levels lower (63). However, none of them fulfill the requirements of a feasible biomarker for endometriosis diagnosis. Also no correlation was found between stage of endometriosis according to ASRM criteria and MMP-2, MMP-9, TIMP-1 and TIMP-2 levels in serum (92), although the results are dissonant, as Malvezzi et al found significantly higher levels of MMP-2 in serum of women with moderate to severe endometriosis compared to milder stages (93).

\section{Polymorphism of MMPs genes in endometriosis}

Endometriosis seems to have some characteristics of genetic disease, but it certainly does not have a clear Mendelian inheritance pattern. The mechanisms of inheritance and a degree of influence of genetic background in endometriosis development are under discussion from decades (94). Numerous studies were performed in order to find polymorphisms of genes, that are associated with the disease development. For example polymorphisms in the estrogen receptor (95), TP53 (96), or glutathione S-transferase M1 (97) were proven to give predisposition to endometriosis. As MMPs seem to be important players in endometriosis occurrence and development, their genetics in the disease were also investigated (98-104). Those studies claim a correlation between single-nucleotide polymorphisms (SNPs) and haplotypes of MMP-2, MMP-7, MMP-9, MMP-12 and MMP-13, TIMP2 and endometriosis risk. Recently a few metaanalysises were published, summarizing those results. Two of them emphasize MMP-1 1607 1G/2G polymorphism in predicting endometriosis risk $(105,106)$. Nevertheless, no such correlation was found for MMP-2 15918 T/C (rs243847), MMP-2 -735 C/T (rs2285053), MMP-3 -1171 5A/6A, MMP-7 -181 A/G (rs11568818), MMP-9 -1562 C/T (rs3918242) and MMP-9 R279Q (rs17576) polymorphisms and endometriosis (107). Obtained results require further studies, especially analysis of haplotypes, as they might be more predictive, then single SNPs.

\section{Future research and treatment perspectives}

Although since decades studies were conducted in order to explain endometriosis etiology, its causes still remain unknown. MMPs together with their inhibitors, as arrangement essential in ECM remodeling, attachment and invasion of endometrium into extrauterine surfaces, are without a doubt important players in the disease development. TIMPs play a protective role in the 
disease etiology, as proven by Bruner et al (53). The presence and role of MMPs in endometriosis is unquestionable, however the exact sequence of events is unclear. It remains obscure, whether changes in their activity occur primarily in uterine cavity, that due to cellular memory allows endometrium fragments implantation into peritoneum, or whether specific conditions in peritoneal cavity (inflammation or other immunological processes) change MMPs activity in endometrial cells discarded from uterus during retrograde menstruation. Moreover, some balance switches in matrix remodeling in eutopic endometrium can be periodic or temporal and vanish just after lesion constitution on ectopic site. What is more, changes of MMPs and TIMPs activity, demonstrated in uterine endometrium from women with endometriosis may also occur after implantation of ectopic lesions, under the influence of processes taking place in peritoneum. Solution of this riddle seems to be hard to find, as it would require prospective study based on endometriotic biopsies in asymptomatic population of women and long-term observation for endometriosis onset. Taking into consideration the incidence rate of 1/1,000 per year, performance of such study on healthy population would by unfeasible and likely unethical. Furthermore, despite extensive research looking for endometriosis biomarkers, its proper diagnosis or clear exclusion still requires invasive procedure (laparoscopy), since many asymptomatic or conditionally symptomatic (subfertility) cases are present.

Except comparison of uterine endometrium from healthy control and women with endometriosis, numerous studies were also conducted in order to determine activity of MMPs and TIMPs in ectopic lesions (summarized in Tables V and VI). These results are also unsettling, probably because of variable activity of MMPs and their inhibitors depending on numerous factors, such as phase of menstrual cycle or lesion type. In addition, the differences in research outcomes perfectly reflect variable role of MMPs in diverse steps of endometriosis development. Sotnikova et al showed, how activity of MMP-2 and TIMP-1 changes in ectopic lesions after their implantation in ectopic lesions in murine model of endometriosis, changing pattern from 'remodeling-favorable' during invasion to 'remodeling-limiting' after lesion formation (58). Change of matrix turnover balance in peritoneal lesion, as well as reactive alteration of the balance in uterus, seems to be promising mechanisms not only for the disease onset but also for the explanation of pathological effects of the disease and symptom occurrence. Therefore, it becomes clear that experiments on human tissue, that are not collected in one, specific point of disease progression, will present unreliable results. As mentioned before, also every lesion type presents diverse results of MMPs and TIMPs activity $(71,81)$. Noteworthy, no correlation was found between American Society of Reproductive Medicine (ASRM) scores and MMPs and TIMPs levels in ovarian endometriomas (108).

Interestingly, changes in MMP-TIMP balance, that occur periodically in menstrual cycle and in endometriosis formation, may not only be technical obstacle in performing studies on endometriosis, but also be an important key to understanding its pathogenesis. As it was described in Table II, bimodal distribution of activity could be observed during physiological menstrual cycle. MMP are activated mainly in menstrual and in lower extend in proliferative phase of the cycle. TIMPs predominate especially in late secretory phase but TIMP-3 also in early menstrual phase. Similar domination of RECK in second part of the cycle was observed (authors' unpublished data). It is undoubtful, that physiological interplay in regulation of endometrial matrix turnover would be responsible for endometrial growth in proliferative phase, endometrial stabilization in secretory phase, as well as endometrial break-down during menstruation and inhibition of endometrial implant formation in peritoneal cavity after menstruation. TIMP/RECK activation in secretory phase that persist in menstrual debris could be a potent protective mechanism. The inhibitory arm of the system is suppressed in eutopic endometrium in cases with endometriosis, so menstrual debris with lower TIMP expression could augment the implantation and lesion formation. It remains to be determined, which factors downregulate inhibitors of MMPs, because then some therapeutic or prophylactic intervention could be considered.

The role of matrix turnover in endometriosis is not unidirectional. As it was explained above, after the formation of endometrial lesions, the MMP-TIMP balance reverse to matrix stabilization by TIMP predominance (58). On the one hand, the matrix remodeling inhibition can be an important protective reaction that prevents invasive growth of existing lesion and implantation of new endometrial fragments. On the other hand, impairment of normal matrix remodeling in peritoneal cavity is a proposed mechanism of ovulatory dysfunction (lutanized unruptured follicle-LUF syndrome), that could be a main cause of endometriosis related infertility. Overactivated TIMPs could reduce tissue break-down, that is necessary in ovulatory rupture. It was proven on animal model of endometrosis, that rats with endometriosis have increased TIMP-1 and unruptured follicle-like phenotype (LUF syndrome). Moreover, neutralization of TIMP-1 in these animals effectively restored ovulation and fertility $(109,110)$.

Recently an effective stimulation protocol dedicated to LUF syndrome was described for humans. In addition to standard ovarian stimulation, the single injection of G-CSF (granulocyte colony stimulating factor) in preovulatory period was administered, causing a significant reduction of LUF syndrome recurrence in comparison to standard ovarian stimulation alone. It is anticipated, that the most important effect of G-CSF in ovulation is leukocyte recruitment and activation in peritoneal cavity (111). This activation of leukocytes leads to secretion of excessive amounts of MMPs and may overcome stoichiometric inhibition of TIMPs. Although this promising therapy is effective, low-cost and safe example of implementation of drug used before in other fields of medicine, further assessment of clinical effectiveness and clear explanation of molecular mechanism is necessary.

In conclusion, although over-activity of MMPs is one of the key pathologies, that lead to endometriosis occurrence, their excessive inhibition in later stages of the disease may have a deep influence on the endometriosis clinical picture. Implementation of novel treatment modalities that could change the ECM remodeling especially in periovulatory period in humans is promising. Selection between recombinant protein or small-molecule drugs with antagonistic or agonistic properties for MMP-TIMP system of interaction or their regulatory miRNA should be performed on basis of safety and clinical feasibility in practice. Therapeutic intervention has to be personalized and suited to the disease stage to shift the balance into correct direction. 
To improve the research in future, every study that includes investigation of MMPs and TIMPs levels should include precise data: A phase of menstruation cycle during sample collection (preferably including sex hormones levels), ectopic lesion localization, its character and morphology. Nevertheless, some studies lack even the most basic information, which is menstrual cycle phase, or even compare the obtained results regardless of the cycle. It seems to distort the results and make collective analysis impossible, since activity of specific agents may differ remarkably between phases of menstrual cycle. On the other hand, certain studies present very complex and extended analysis, comparing obtained results to phase of the cycle and lesions type, such as Londero et al (86) Including all the additional information about used samples seems to be essential for correct and conclusive analysis of results, that will later contribute to firmer understanding of MMPs and TIMPs role in endometriosis etiology. Moreover, collecting, processing and storage of the biological material should be performed with unified, standardized approach, such as proposed by World Endometriosis Research Foundation (112).

RECK is an important player in maintaining balance between MMPs and their inhibitors. Although it is very widely investigated in other diseases (i.e., metastases, cancer invasion), research on its role in endometriosis is still sparse. It has been proven to have a pivotal role in many pathological conditions, as being a cellular membrane bound inhibitor closely resembles the activity of TIMPs. Therefore it seems to be necessary to complete previous knowledge of endometriosis and MMPs with studies on RECK.

Although the role of MMPs and their inhibitors in endometriosis etiology is indisputable, clinical usage of this knowledge is still doubtful at the moment. MMPs and their inhibitors regulate enormous number of both physiological and pathological processes. Therefore, any interference in the perfect balance between those agents may have severe consequences. Unfortunately no agents are known, that would work selectively on uterine endometrium or ectopic lesions, but some successful approaches in nonspecific shifting MMP-TIMP balance in periovulatory period were mentioned above (111). Since TIMP, by down regulating MMP activity, also limits development of new ectopic lesions, usage of anti-MMPs agents may have a relevant impact on endometriosis prevention. The adverse effects of the therapy can by limited since the treatment could be periodic and selectively targeted to menstrual cycle. However, further studies are required, in order to clarify if inhibiting metalloproteinases and ECM remodeling would not only arrest occurrence of new lesions, but also limit progression of existing ones.

\section{Acknowledgements}

Not applicable.

\section{Funding}

The present study was supported by National Center for Science (NCN) (grant nos. DEC-2011/03/N/NZ5/05899 and DEC-2013/09/B/NZ5/00790). RBM is beneficent of the International PhD Projects Programme (MPD) of Foundation for Polish Science (grant no. MPD/2009/5/styp5), co-financed from
European Union Regional Development Found, and Polpharma Scientific Foundation scholarship (grant no. 1/19.03.2013).

\section{Availability of data and materials}

Not applicable.

\section{Authors' contributions}

MB and RBM were involved in the study design, literature analysis, manuscript writing and submission. PKW was involved in the study design, literature analysis, manuscript writing and provided scientific advise. All authors read, review and approved the final manuscript.

\section{Ethics approval and consent to participate}

Not applicable.

\section{Patient consent for publication}

Not applicable.

\section{Competing interests}

The authors declare that they have no competing interests.

\section{References}

1. Burney RO and Giudice LC: Pathogenesis and pathophysiology of endometriosis. Fertil Steril 98: 511-519, 2012.

2. Sampson JA: Metastatic or embolic endometriosis, due to the menstrual dissemination of endometrial tissue into the venous circulation. Am J Pathol 3: 93-110.143, 1927.

3. Halme J, Hammond MG, Hulka JF, Raj SG and Talbert LM: Retrograde menstruation in healthy women and in patients with endometriosis. Obstet Gynecol 64: 151-154, 1984.

4. BRENDA: The Comprehensive Enzyme Information System. www.brenda-enzymes.org.

5. Verma RP and Hansch C: Matrix metalloproteinases (MMPs): Chemical-biological functions and (Q)SARs. Bioorg Med Chem 15: 2223-2268, 2007

6. Rodgers WH, Osteen KG, Matrisian LM, Navre M, Giudice LC and Gorstein F: Expression and localization of matrilysin, a matrix metalloproteinase, in human endometrium during the reproductive cycle. Am J Obstet Gynecol 168: 253-260, 1993.

7. Rodgers WH, Matrisian LM, Giudice LC, Dsupin B, Cannon P, Svitek C, Gorstein F and Osteen KG: Patterns of matrix metalloproteinase expression in cycling endometrium imply differential functions and regulation by steroid hormones. J Clin Invest 94: 946-953, 1994.

8. Gaide Chevronnay HP, Selvais C, Emonard H, Galant C, Marbaix E and Henriet P: Regulation of matrix metalloproteinases activity studied in human endometrium as a paradigm of cyclic tissue breakdown and regeneration. Biochim Biophys Acta 1824: 146-156, 2012.

9. Amălinei C, Căruntu ID, Giuşcă SE and Bălan RA: Matrix metalloproteinases involvement in pathologic conditions. Rom J Morphol Embryol 51: 215-228, 2010.

10. Di Nezza LA, Misajon A, Zhang J, Jobling T, Quinn MA, Ostör AG, Nie G, Lopata A and Salamonsen LA: Presence of active gelatinases in endometrial carcinoma and correlation of matrix metalloproteinase expression with increasing tumor grade and invasion. Cancer 94: 1466-1475, 2002.

11. Takahashi C, Sheng Z, Horan TP, Kitayama H, Maki M, Hitomi K, Kitaura Y, Takai S, Sasahara RM, Horimoto A, et al: Regulation of matrix metalloproteinase-9 and inhibition of tumor invasion by the membrane-anchored glycoprotein RECK. Proc Natl Acad Sci USA 95: 13221-13226, 1998.

12. Matrisian LM: The matrix-degrading metalloproteinases. Bioessays 14: 455-463, 1992. 
13. Murphy G: Tissue inhibitors of metalloproteinases. Genome Biol 12: 233, 2011

14. Wang WM, Ge G, Lim NH, Nagase H and Greenspan DS TIMP-3 inhibits the procollagen N-proteinase ADAMTS-2. Biochem J 398: 515-519, 2006.

15. Kashiwagi M, Tortorella M, Nagase $\mathrm{H}$ and Brew K: TIMP-3 is a potent inhibitor of aggrecanase 1 (ADAM-TS4) and aggrecanase 2 (ADAM-TS5). J Biol Chem 276: 12501-12504, 2001.

16. Amour A, Slocombe PM, Webster A, Butler M, Knight CG, Smith BJ, Stephens PE, Shelley C, Hutton M, Knäuper V, et al: TNF-alpha converting enzyme (TACE) is inhibited by TIMP-3. FEBS Lett 435: 39-44, 1998.

17. Amour A, Knight CG, Webster A, Slocombe PM, Stephens PE, Knäuper V, Docherty AJ and Murphy G: The in vitro activity of ADAM-10 is inhibited by TIMP-1 and TIMP-3. FEBS Lett 473: 275-279, 2000.

18. Seals DF and Courtneidge SA: The ADAMs family of metalloproteases: Multidomain proteins with multiple functions. Genes Dev 17: 7-30, 2003.

19. Alexius-Lindgren M, Andersson E, Lindstedt I and Engström W: The RECK gene and biological malignancy-its significance in angiogenesis and inhibition of matrix metalloproteinases. Anticancer Res 34: 3867-3873, 2014

20. Clark JC, Thomas DM, Choong PF and Dass CR: RECK-a newly discovered inhibitor of metastasis with prognostic significance in multiple forms of cancer. Cancer Metastasis Rev 26: 675-683, 2007.

21. Bruner-Tran KL, Eisenberg E, Yeaman GR, Anderson TA, McBean J and Osteen KG: Steroid and cytokine regulation of matrix metalloproteinase expression in endometriosis and the establishment of experimental endometriosis in nude mice. J Clin Endocrinol Metab 87: 4782-4791, 2002.

22. Osteen KG, Bruner KL and Sharpe-Timms KL: Steroid and growth factor regulation of matrix metalloproteinase expression and endometriosis. Semin Reprod Endocrinol 14: 247-255, 1996.

23. Sharpe-Timms KL and Cox KE: Paracrine regulation of matrix metalloproteinase expression in endometriosis. Ann N Y Acad Sci 955: 147-158, 396-406, 2002.

24. Gezer A and Oral E: Progestin therapy in endometriosis. Womens Health (Lond) 11: 643-652, 2015.

25. Osteen KG, Rodgers WH, Gaire M, Hargrove JT, Gorstein F and Matrisian LM: Stromal-epithelial interaction mediates steroidal regulation of metalloproteinase expression in human endometrium. Proc Natl Acad Sci USA 91: 10129-10133, 1994.

26. Marbaix E, Donnez J, Courtoy PJ and Eeckhout Y: Progesterone regulates the activity of collagenase and related gelatinases $\mathrm{A}$ and B in human endometrial explants. Proc Natl Acad Sci USA 89: 11789-11793, 1992.

27. Sillem M,Prifti S, Koch A, Neher M, Jauckus J and Runnebaum B Regulation of matrix metalloproteinases and their inhibitors in uterine endometrial cells of patients with and without endometriosis. Eur J Obstet Gynecol Reprod Biol 95: 167-174, 2001.

28. Mönckedieck V, Sannecke C, Husen B, Kumbartski M, Kimmig R, Tötsch M, Winterhager $\mathrm{E}$ and Grümmer R: Progestins inhibit expression of MMPs and of angiogenic factors in human ectopic endometrial lesions in a mouse model. Mol Hum Reprod 15: 633-643, 2009.

29. Sillem M, Prifti S, Neher M and Runnebaum B: Extracellular matrix remodelling in the endometrium and its possible relevance to the pathogenesis of endometriosis. Hum Reprod Update 4: 730-735, 1998

30. Bruner-Tran KL, Zhang Z, Eisenberg E, Winneker RC and Osteen KG: Down-regulation of endometrial matrix metalloproteinase- 3 and -7 expression in vitro and therapeutic regression of experimental endometriosis in vivo by a novel nonsteroida progesterone receptor agonist, tanaproget. J Clin Endocrinol Metab 91: 1554-1560, 2006.

31. Shan B, Li W, Yang SY and Li ZR: Estrogen up-regulates MMP2/9 expression in endometrial epithelial cell via VEGF-ERK1/2 pathway. Asian Pac J Trop Med 6: 826-830, 2013.

32. Huang HF, Hong LH, Tan Y and Sheng JZ: Matrix metalloproteinase 2 is associated with changes in steroid hormones in the sera and peritoneal fluid of patients with endometriosis. Fertil Steril 81: 1235-1239, 2004

33. Ahn JH, Choi YS and Choi JH: Leptin promotes human endometriotic cell migration and invasion by up-regulating MMP-2 through the JAK2/STAT3 signaling pathway. Mol Hum Reprod 21: 792-802, 2015.
34. Sevket O, Sevket A, Molla T, Buyukpinarbasıl1 N, Uysal O, Y1lmaz B, Dane B and Kelekc1 S: Somatostatin analogs regress endometriotic implants in rats by decreasing implant levels of vascular endothelial growth factor and matrix metaloproteinase 9. Reprod Sci 20: 639-645, 2013

35. Yilmaz B, Kilic S, Aksakal O, Ertas IE, Tanrisever GG, Aksoy Y, Lortlar N, Kelekci S and Gungor T: Melatonin causes regression of endometriotic implants in rats by modulating angiogenesis, tissue levels of antioxidants and matrix metalloproteinases. Arch Gynecol Obstet 292: 209-216, 2015.

36. Parkin KL and Fazleabas AT: Uterine leukocyte function and dysfunction: A hypothesis on the impact of endometriosis. Am J Reprod Immunol 75: 411-417, 2016.

37. Braundmeier AG and Nowak RA: Cytokines regulate matrix metalloproteinases in human uterine endometrial fibroblast cells through a mechanism that does not involve increases in extracellular matrix metalloproteinase inducer. Am J Reprod Immunol 56: 201-214, 2006.

38. Chegini N: TGF-beta system: The principal profibrotic mediator of peritoneal adhesion formation. Semin Reprod Med 26 : 298-312, 2008

39. Singer CF, Marbaix E, Lemoine P, Courtoy PJ and Eeckhout Y: Local cytokines induce differential expression of matrix metalloproteinases but not their tissue inhibitors in human endometrial fibroblasts. Eur J Biochem 259: 40-45, 1999.

40. Mulayim N, Savlu A, Guzeloglu-Kayisli O, Kayisli UA and Arici A: Regulation of endometrial stromal cell matrix metalloproteinase activity and invasiveness by interleukin-8. Fertil Steril 81 (Suppl 1): S904-S911, 2004.

41. Singer CF, Marbaix E, Kokorine I, Lemoine P, Donnez J, Eeckhout $\mathrm{Y}$ and Courtoy PJ: Paracrine stimulation of interstitial collagenase (MMP-1) in the human endometrium by interleukin 1alpha and its dual block by ovarian steroids. Proc Natl Acad Sci USA 94: 10341-10345, 1997.

42. Khoufache K, Bondza PK, Harir N, Daris M, Leboeuf M, Mailloux J, Lemyre M, Foster W and Akoum A: Soluble human IL-1 receptor type 2 inhibits ectopic endometrial tissue implantation and growth: Identification of a novel potential target for endometriosis treatment. Am J Pathol 181: $1197-1205,2012$

43. Quattrone F, Sanchez AM, Pannese M, Hemmerle T, Viganò P, Candiani M, Petraglia F, Neri D and Panina-Bordignon P: The targeted delivery of interleukin 4 inhibits development of endometriotic lesions in a mouse model. Reprod Sci 22: 1143-1152, 2015.

44. Kumar R, Clerc AC, Gori I, Russell R, Pellegrini C, Govender L, Wyss JC, Golshayan D and Canny GO: Lipoxin $\mathrm{A}_{4}$ prevents the progression of de novo and established endometriosis in a mouse model by attenuating prostaglandin $\mathrm{E}_{2}$ production and estrogen signaling. PLoS One 9: e89742, 2014.

45. Lee J, Banu SK, Subbarao T, Starzinski-Powitz A and Arosh JA Selective inhibition of prostaglandin E2 receptors EP2 and EP4 inhibits invasion of human immortalized endometriotic epithelial and stromal cells through suppression of metalloproteinases. Mol Cell Endocrinol 332: 306-313, 2011

46. Edwards DR, Murphy G, Reynolds JJ, Whitham SE, Docherty AJ, Angel $\mathrm{P}$ and Heath JK: Transforming growth factor beta modulates the expression of collagenase and metalloproteinase inhibitor. EMBO J 6: 1899-1904, 1987

47. Osteen KG, Keller NR, Feltus FA and Melner MH: Paracrine regulation of matrix metalloproteinase expression in the normal human endometrium. Gynecol Obstet Invest 48 (Suppl 1): S2-S13, 1999.

48. Braundmeier AG, Fazleabas AT, Lessey BA, Guo H, Toole BP and Nowak RA: Extracellular matrix metalloproteinase inducer regulates metalloproteinases in human uterine endometrium. J Clin Endocrinol Metab 91: 2358-2365, 2006.

49. Bruner KL, Eisenberg E, Gorstein F and Osteen KG: Progesterone and transforming growth factor-beta coordinately regulate suppression of endometrial matrix metalloproteinases in a model of experimental endometriosis. Steroids 64: 648-653, 1999.

50. Witz CA, Dechaud H, Montoya-Rodriguez IA, Thomas MR, Nair AS, Centonze VE and Schenken RS: An in vitro model to study the pathogenesis of the early endometriosis lesion. Ann N Y Acad Sci 955: 296-307; discussion 340-342, 396-406, 2002.

51. Koks CA, Demir Weusten AY, Groothuis PG, Dunselman GA, de Goeij AF and Evers JL: Menstruum induces changes in mesothelial cell morphology. Gynecol Obstet Invest 50: 13-18, 2000.

52. Zhang J and Salamonsen LA: In vivo evidence for active matrix metalloproteinases in human endometrium supports their role in tissue breakdown at menstruation. J Clin Endocrinol Metab 87: 2346-2351, 2002 
53. Bruner KL, Matrisian LM, Rodgers WH, Gorstein F and Osteen KG: Suppression of matrix metalloproteinases inhibits establishment of ectopic lesions by human endometrium in nude mice. J Clin Invest 99: 2851-2857, 1997.

54. Malik S, Day K, Perrault I, Charnock-Jones DS and Smith SK: Menstrual effluent in endometriosis shows no difference in volume, VEGF-A, MMP2 and MMP9 or sFLT. Reprod Biomed Online 12: 174-181, 2006

55. Eisermann J, Gast MJ, Pineda J, Odem RR and Collins JL: Tumor necrosis factor in peritoneal fluid of women undergoing laparoscopic surgery. Fertil Steril 50: 573-579, 1988.

56. Taketani Y, Kuo TM and Mizuno M: Comparison of cytokine levels and embryo toxicity in peritoneal fluid in infertile women with untreated or treated endometriosis. Am J Obstet Gynecol 167: 265-270, 1992.

57. Oosterlynck DJ, Meuleman C, Waer M and Koninckx PR Transforming growth factor-beta activity is increased in peritoneal fluid from women with endometriosis. Obstet Gynecol 83: 287-292, 1994

58. Sotnikova NY, Antsiferova YS, Posiseeva LV, Shishkov DN, Posiseev DV and Filippova ES: Mechanisms regulating invasiveness and growth of endometriosis lesions in rat experimental model and in humans. Fertil Steril 93: 2701-2705, 2010.

59. Gilabert-Estellés J, Ramón LA, España F, Gilabert J, Vila V, Réganon E, Castelló R, Chirivella M and Estellés A: Expression of angiogenic factors in endometriosis: Relationship to fibrinolytic and metalloproteinase systems. Hum Reprod 22: 2120-2127, 2007.

60. Liu H, Wang J, Wang H, Tang N, Li Y, Zhang Y and Hao T: Correlation between matrix metalloproteinase- 9 and endometriosis. Int J Clin Exp Pathol 8: 13399-13404, 2015.

61. Szamatowicz J, Laudański P and Tomaszewska I: Matrix metalloproteinase-9 and tissue inhibitor of matrix metalloproteinase-1: A possible role in the pathogenesis of endometriosis Hum Reprod 17: 284-288, 2002.

62. Laudanski P, Szamatowicz J and Ramel P: Matrix metalloproteinase-13 and membrane type-1 matrix metalloproteinase in peritoneal fluid of women with endometriosis. Gynecol Endocrinol 21: 106-110, 2005.

63. Sharpe-Timms KL, Keisler LW, McIntush EW and Keisler DH: Tissue inhibitor of metalloproteinase-1 concentrations are attenuated in peritoneal fluid and sera of women with endometriosis and restored in sera by gonadotropin-releasing hormone agonist therapy. Fertil Steril 69: 1128-1134, 1998.

64. Sharpe-Timms KL, Zimmer RL, Jolliff WJ, Wright JA, Nothnick WB and Curry TE: Gonadotropin-releasing hormone agonist $(\mathrm{GnRH}-\mathrm{a})$ therapy alters activity of plasminogen activators, matrix metalloproteinases, and their inhibitors in rat models for adhesion formation and endometriosis: Potentia GnRH-a-regulated mechanisms reducing adhesion formation. Fertil Steril 69: 916-923, 1998.

65. Ulukus M, Cakmak H and Arici A: The role of endometrium in endometriosis. J Soc Gynecol Investig 13: 467-476, 2006.

66. Collette T, Bellehumeur C, Kats R, Maheux R, Mailloux J, Villeneuve $M$ and Akoum A: Evidence for an increased release of proteolytic activity by the eutopic endometrial tissue in women with endometriosis and for involvement of matrix metalloproteinase-9. Hum Reprod 19: 1257-1264, 2004.

67. Collette T, Maheux R, Mailloux J and Akoum A: Increased expression of matrix metalloproteinase-9 in the eutopic endometrial tissue of women with endometriosis. Hum Reprod 21: 3059-3067, 2006.

68. Di Carlo C, Bonifacio M, Tommaselli GA, Bifulco G, Guerra G and Nappi C: Metalloproteinases, vascular endothelial growth factor, and angiopoietin 1 and 2 in eutopic and ectopic endometrium. Fertil Steril 91: 2315-2323, 2009.

69. Szymanowski K, Mikolajczyk M, Wirstlein P and Dera-Szymanowska A: Matrix metalloproteinase-2 (MMP-2), MMP-9, tissue inhibitor of matrix metalloproteinases (TIMP-1) and transforming growth factor- $\beta 2$ (TGF-U2) expression in eutopic endometrium of women with peritoneal endometriosis. Ann Agric Environ Med 23: 649-653, 2016.

70. Wenzl RJ and Heinzl H: Localization of matrix metalloproteinase-2 in uterine endometrium and ectopic implants. Gynecol Obstet Invest 45: 253-257, 1998.

71. Uzan C, Cortez A, Dufournet C, Fauvet R, Siffroi JP and Daraï E: Eutopic endometrium and peritoneal, ovarian and bowel endometriotic tissues express a different profile of matrix metalloproteinases-2, -3 and -11 , and of tissue inhibitor metalloproteinases-1 and -2. Virchows Archiv 445: 603-609, 2004
72. Chung HW, Lee JY, Moon HS, Hur SE, Park MH, Wen Y and Polan ML: Matrix metalloproteinase-2, membranous type 1 matrix metalloproteinase, and tissue inhibitor of metalloproteinase-2 expression in ectopic and eutopic endometrium. Fertil Steril 78: 787-795, 2002.

73. Gilabert-Estellés J, Estellés A, Gilabert J, Castelló R, España F, Falcó C, Romeu A, Chirivella M, Zorio E and Aznar J: Expression of several components of the plasminogen activator and matrix metalloproteinase systems in endometriosis. Hum Reprod 18 $1516-1522,2003$

74. Ramón L, Gilabert-Estellés J, Castelló R, Gilabert J, España F, Romeu A, Chirivella M, Aznar J and Estellés A: mRNA analysis of several components of the plasminogen activator and matrix metalloproteinase systems in endometriosis using a real-time quantitative RT-PCR assay. Hum Reprod 20: 272-278, 2005.

75. Chung HW, Wen Y, Chun SH, Nezhat C, Woo BH and Lake Polan M: Matrix metalloproteinase-9 and tissue inhibitor of metalloproteinase-3 mRNA expression in ectopic and eutopic endometrium in women with endometriosis: A rationale for endometriotic invasiveness. Fertil Steril 75: 152-159, 2001.

76. Pan H, Sheng JZ, Tang L, Zhu R, Zhou TH and Huang HF: Increased expression of $\mathrm{c}$-fos protein associated with increased matrix metalloproteinase-9 protein expression in the endometrium of endometriotic patients. Fertil Steril 90: 1000-1007, 2008

77. Gaetje R, Holtrich U, Engels K, Kourtis K, Cikrit E, Kissler S, Rody A, Karn T and Kaufmann M: Expression of membrane-type 5 matrix metalloproteinase in human endometrium and endometriosis. Gynecol Endocrinol 23: 567-573, 2007.

78. Laudanski P, Charkiewicz R, Kuzmicki M, Szamatowicz J, Świątecka J, Mroczko B and Niklinski J: Profiling of selected angiogenesis-related genes in proliferative eutopic endometrium of women with endometriosis. Eur J Obstet Gynecol Reprod Biol 172: 85-92, 2014

79. Lu XE, Ning WX, Dong MY, Liu AX, Jin F and Huang HF Vascular endothelial growth factor and matrix metalloproteinase-2 expedite formation of endometriosis in the early stage ICR mouse model. Fertil Steril 86 (4 Suppl): S1175-S1181, 2006.

80. Cox KE, Piva M and Sharpe-Timms KL: Differential regulation of matrix metalloproteinase-3 gene expression in endometriotic lesions compared with endometrium. Biol Reprod 65: 1297-1303, 2001.

81. Ueda M, Yamashita Y, Takehara M, Terai Y, Kumagai K, Ueki K, Kanda K, Hung YC and Ueki M: Gene expression of adhesion molecules and matrix metalloproteinases in endometriosis. Gynecol Endocrinol 16: 391-402, 2002

82. Kokorine I, Nisolle M, Donnez J, Eeckhout Y, Courtoy PJ and Marbaix E: Expression of interstitial collagenase (matrix metalloproteinase-1) is related to the activity of human endometriotic lesions. Fertil Steril 68: 246-251, 1997.

83. Cominelli A, Gaide Chevronnay HP, Lemoine P, Courtoy PJ, Marbaix E and Henriet P: Matrix metalloproteinase-27 is expressed in CD163+/CD206+ M2 macrophages in the cycling human endometrium and in superficial endometriotic lesions. Mol Hum Reprod 20: 767-775, 2014.

84. Mizumoto H, Saito T, Ashihara K, Nishimura M, Takehara M, Tanaka R, Ito E and Kudo R: Expression of matrix metalloproteinases in ovarian endometriomas: Immunohistochemical study and enzyme immunoassay. Life Sci 71: 259-273, 2002.

85. Shaco-Levy R, Sharabi S, Benharroch D, Piura B and Sion-Vardy N: Matrix metalloproteinases 2 and 9, E-cadherin, and beta-catenin expression in endometriosis, low-grade endometrial carcinoma and non-neoplastic eutopic endometrium. Eur J Obstet Gynecol Reprod Biol 139: 226-232, 2008.

86. Londero AP, Calcagno A, Grassi T, Marzinotto S, Orsaria M, Beltrami CA, Marchesoni D and Mariuzzi L: Survivin, MMP-2, MT1-MMP, and TIMP-2: Their impact on survival, implantation, and proliferation of endometriotic tissues. Virchows Arch 461: 589-599, 2012

87. Meola J, Rosa e Silva JC, Dentillo DB, da Silva WA Jr, Veiga-Castelli LC, Bernardes LA, Ferriani RA, de Paz CC, Giuliatti S and Martelli L: Differentially expressed genes in eutopic and ectopic endometrium of women with endometriosis. Fertil Steril 93: 1750-1773, 2010.

88. Liu XJ, He YL and Peng DX: Expression of metalloproteinase-9 in ectopic endometrium in women with endometriosis. Di Yi Jun Yi Da Xue Xue Bao 22: 467-469, 2002.

89. Gottschalk C, Malberg K, Arndt M, Schmitt J, Roessner A, Schultze D, Kleinstein J and Ansorge S: Matrix metalloproteinases and TACE play a role in the pathogenesis of endometriosis. Adv Exp Med Biol 477: 483-486, 2000 
90. Ria R, Loverro G, Vacca A, Ribatti D, Cormio G, Roccaro AM and Selvaggi L: Angiogenesis extent and expression of matrix metalloproteinase-2 and -9 agree with progression of ovarian endometriomas. Eur J Clin Invest 32: 199-206, 2002.

91. Nisenblat V, Bossuyt PM, Shaikh R, Farquhar C, Jordan V, Scheffers CS, Mol BW, Johnson N and Hull ML: Blood biomarkers for the non-invasive diagnosis of endometriosis. Cochrane Database Syst Rev: Cd012179, 2016.

92. Salata IM, Stojanovic N, Cajdler-Łuba A, Lewandowski KC and Lewiński A: Gelatinase A (MM-2), gelatinase B (MMP-9) and their inhibitors (TIMP 1, TIMP-2) in serum of women with endometriosis: Significant correlation between MMP-2, MMP-9 and their inhibitors without difference in levels of matrix metalloproteinases and tissue inhibitors of metalloproteinases in relation to the severity of endometriosis. Gynecol Endocrinol 24: 326-330, 2008.

93. Malvezzi H, Aguiar VG, Paz CC, Tanus-Santos JE, Penna IA and Navarro PA: Increased circulating MMP-2 levels in infertile patients with moderate and severe pelvic endometriosis. Reprod Sci 20: 557-562, 2013.

94. Kennedy S: Is there a genetic basis to endometriosis? Semin Reprod Endocrinol 15: 309-318, 1997.

95. Georgiou I, Syrrou M, Bouba I, Dalkalitsis N, Paschopoulos M, Navrozoglou I and Lolis D: Association of estrogen receptor gene polymorphisms with endometriosis. Fertil Steril 72: 164-166, 1999

96. Chang CC, Hsieh YY, Tsai FJ, Tsai CH, Tsai HD and Lin CC: The proline form of $\mathrm{p} 53$ codon 72 polymorphism is associated with endometriosis. Fertil Steril 77: 43-45, 2002.

97. Baranova H, Bothorishvilli R, Canis M, Albuisson E, Perriot S, Glowaczower E, Bruhat MA, Baranov V and Malet P: Glutathione S-transferase M1 gene polymorphism and susceptibility to endometriosis in a French population. Mol Hum Reprod 3: 775-780, 1997

98. Han YJ, Kim HN, Yoon JK, Yi SY, Moon HS, Ahn JJ, Kim HL and Chung HW: Haplotype analysis of the matrix metalloproteinase-9 gene associated with advanced-stage endometriosis. Fertil Steril 91: 2324-2330, 2009.

99. Saare M, Lamp M, Kaart T, Karro H, Kadastik U, Metspalu A, Peters $M$ and Salumets A: Polymorphisms in MMP-2 and MMP-9 promoter regions are associated with endometriosis. Fertil Steril 94: 1560-1563, 2010.

100. Shan K, Ying W, Jian-Hui Z, Wei G, Na W and Yan L: The function of the SNP in the MMP1 and MMP3 promoter in susceptibility to endometriosis in China. Mol Hum Reprod 11: 423-427, 2005.

101. Shan K, Lian-Fu Z, Hui D, Wei G, Na W, Xia J and Yan L: Polymorphisms in the promoter regions of the matrix metalloproteinases-7, -9 and the risk of endometriosis and adenomyosis in China. Mol Hum Reprod 12: 35-39, 2006.

102. Borghese B, Chiche JD, Vernerey D, Chenot C, Mir O, Bijaoui G, Bonaiti-Pellié $\mathrm{C}$ and Chapron $\mathrm{C}$ : Genetic polymorphisms of matrix metalloproteinase 12 and 13 genes are implicated in endometriosis progression. Hum Reprod 23: 1207-1213, 2008.
103. Cho YJ, Kim NH, Jeong KA, Lee JY, Moon HS, Kim HL and Chung HW: Association between MMP-2 and TIMP-2 gene polymorphisms and advanced-stage endometriosis in Korean women. Am J Reprod Immunol 69: 73-84, 2013.

104. Kang S, Zhao XW, Wang N, Chen SC, Zhou RM and Li Y: Association of polymorphisms of the MMP-2 and TIMP-2 genes with the risk of endometriosis in North Chinese women. Fertil Steril 90: 2023-2029, 2008.

105. Ye H, He Y, Wang J, Song T, Lan Z, Zhao Y and Xi M: Effect of matrix metalloproteinase promoter polymorphisms on endometriosis and adenomyosis risk: Evidence from a meta-analysis. J Genet 95: 611-619, 2016.

106. Yang H, Liu J, Fan Y, Guo Q, Ge L, Yu N, Zheng X, Dou Y and Zheng S: Associations between various possible promoter polymorphisms of MMPs genes and endometriosis risk: A meta-analysis. Eur J Obstet Gynecol Reprod Biol 205: 174-188, 2016.

107. Xin L, Hou Q, Xiong QI and Ding X: Association between matrix metalloproteinase-2 and matrix metalloproteinase-9 polymorphisms and endometriosis: A systematic review and meta-analysis. Biomed Rep 3: 559-565, 2015

108. Protopapas A, Markaki S, Mitsis T, Milingos D, Athanasiou S, Haidopoulos D, Loutradis D and Antsaklis A: IImmunohistochemical expression of matrix metalloproteinases, their tissue inhibitors, and cathepsin-D in ovarian endometriosis: Correlation with severity of disease. Fertil Steril 94: 2470-2472, 2010

109. Stilley JA, Birt JA, Nagel SC, Sutovsky M, Sutovsky P and Sharpe-Timms KL: Neutralizing TIMP1 restores fecundity in a rat model of endometriosis and treating control rats with TIMP1 causes anomalies in ovarian function and embryo development. Biol Reprod 83: 185-194, 2010.

110. Kaya H and Oral B: Effect of ovarian involvement on the frequency of luteinized unruptured follicle in endometriosis. Gynecol Obstet Invest 48: 123-126, 1999.

111. Shibata T, Makinoda S, Waseda T, Tomizawa H, Fujii R and Utsunomiya T: Granulocyte colony-stimulating factor as a potential inducer of ovulation in infertile women with luteinized unruptured follicle syndrome. Transl Res 171: 63-70, 2016.

112. Fassbender A, Rahmioglu N, Vitonis AF, Viganò P, Giudice LC, D'Hooghe TM, Hummelshoj L, Adamson GD, Becker CM, Missmer SA, et al: World endometriosis research foundation endometriosis phenome and biobanking harmonisation project: IV. Tissue collection, processing, and storage in endometriosis research. Fertil Steril 102: 1244-1253, 2014.

This work is licensed under a Creative Commons Attribution-NonCommercial-NoDerivatives 4.0 International (CC BY-NC-ND 4.0) License. 